\title{
Operations to be Performed in the Waste Package Dry Remediation Cell
}

\author{
N. E. Cole \\ R. K. Elwood
}

October 2003

Idaho National Engineering and Environmental Laboratory Bechtel BWXT Idaho, LLC 


\title{
Operations to be Performed in the Waste Package Dry Remediation Cell
}

\author{
Norman E. Cole \\ Randy K. Elwood
}

October 2003

Idaho National Engineering and Environmental Laboratory Idaho Falls, Idaho 83415

\author{
Prepared for the \\ Bechtel SAIC Company \\ Yucca Mountain Project \\ Under DOE Idaho Operations Office \\ Contract DE-AC07-99ID13727
}




\section{CONTENTS}

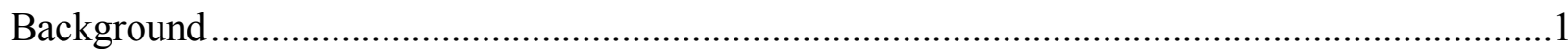

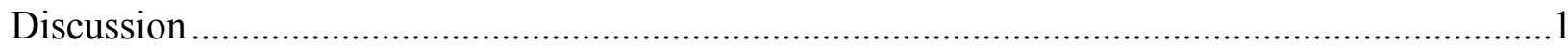

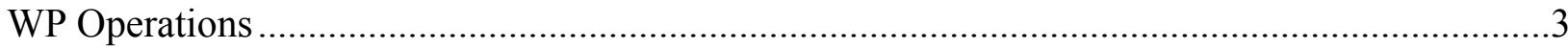

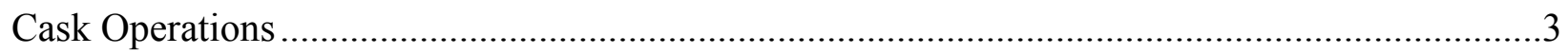

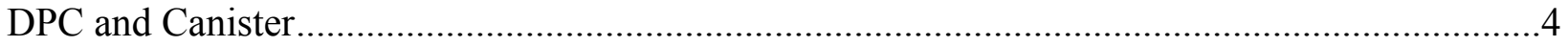

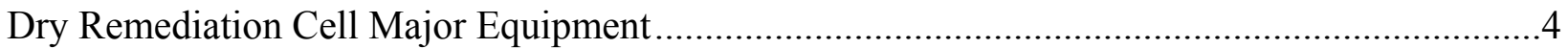

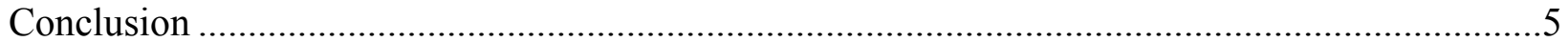




\section{OPERATIONS TO BE PERFORMED IN THE WASTE PACKAGE DRY REMEDIATION CELL}

\section{Background}

The proposed Dry Transfer Facility (DTF) is a production facility relying on planned throughput amounts with minimal non-productive time. In the event of an off-normal situation with any of the transfer containers brought into the DTF for repackaging, an alternate location for resolution of these incidents is recommended.

A proposed Dry Remediation Cell would allow the process line in the DTF to continue normal SNF/HLW packing and disposal operations to meet production schedules while an off-normal event is resolved in this additional facility. Shipping casks, WPs, DPCs, Overpacks, or canisters could be moved directly into the proposed Dry Remediation Cell for evaluation, development of corrective actions, and resolution of off-normal events. The dry cell will be capable of lifting and moving fully loaded casks, WPs, DPCs, Overpacks, and canisters. The cell will also have the capability to open any of the above containers using standard handling techniques, including such tools as wrenches, cutting devices, drills, and other equipment, as required. A function of the dry cell will be to transfer the contents of the issue containers into other storage or transfer containers, as determined by operations. The dry cell will not be a production facility requiring pre-determined throughput amounts, but will be utilized as a facility to remediate off-normal conditions that may occur in the DTF.

\section{Discussion}

Figures 1 shows a general arrangement and layout of a proposed dry cell.

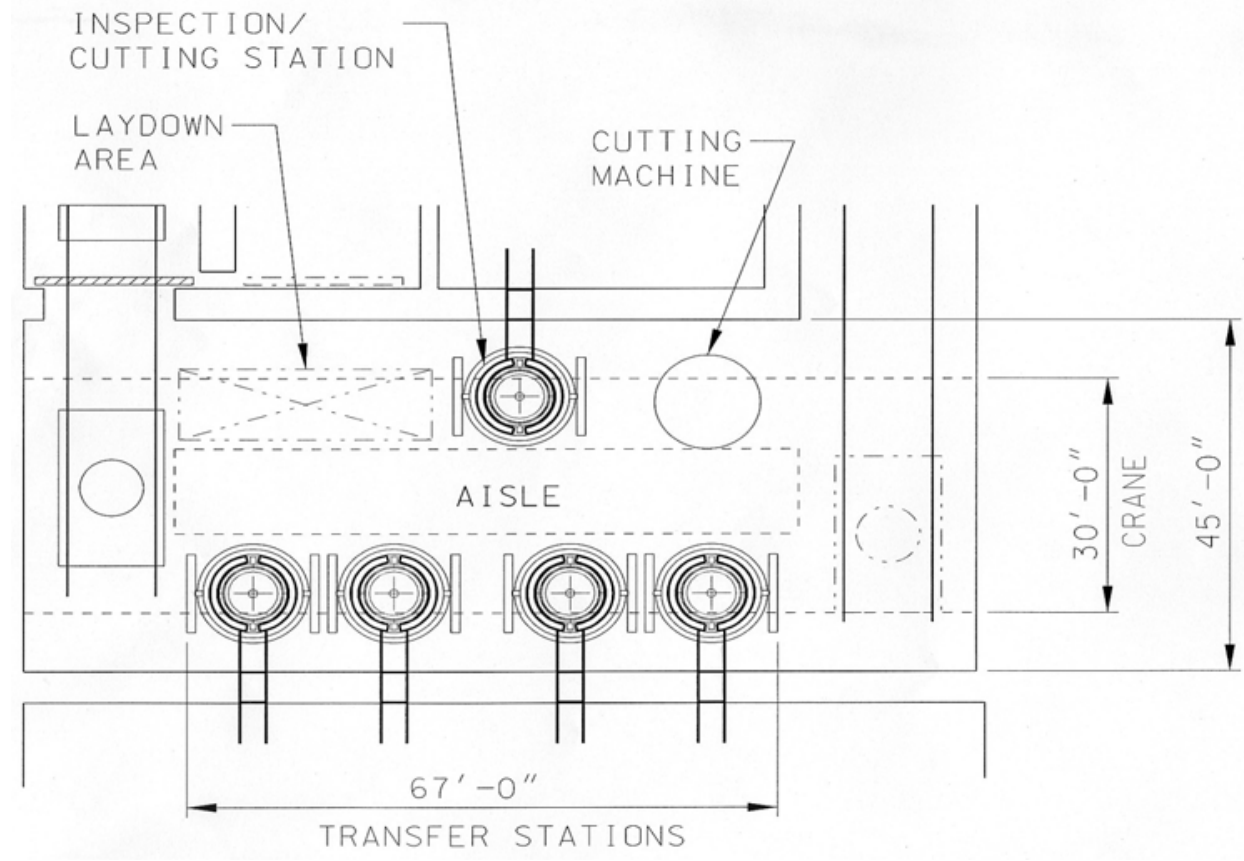

Figure 1. Dry Remediation Cell Floor Plan 
The proposed dry cell will have two stands for supporting casks, WPs, and Overpacks. Each stand will be capable of holding any combination of casks, WPs, or Overpacks, as necessary, and will be used for transferring the contents of those containers. The dry cell will also contain an inspection/cutting station for holding DPCs or other canisters for examination, repair, or cutting them open, and for transferring their contents into a cask or WP, as necessary. This single station will be used for off-normal DPCs or canisters.

As shown in Figure 2, each stand will have two sets of master-slave manipulators. One set will be located at each port for use on the top of the stand at each cask, WP, DPC, Overpack, or canister. At each set of master-slave manipulators will be a shielded viewing window. On the opposite side of the dry cell from the stands will be a general workstation with one set of masterslave manipulators on the first floor and a second set of master-slave manipulators on the second floor. These manipulators will be used to perform inspections and repairs, clean containers, cut containers, and other task, as required.

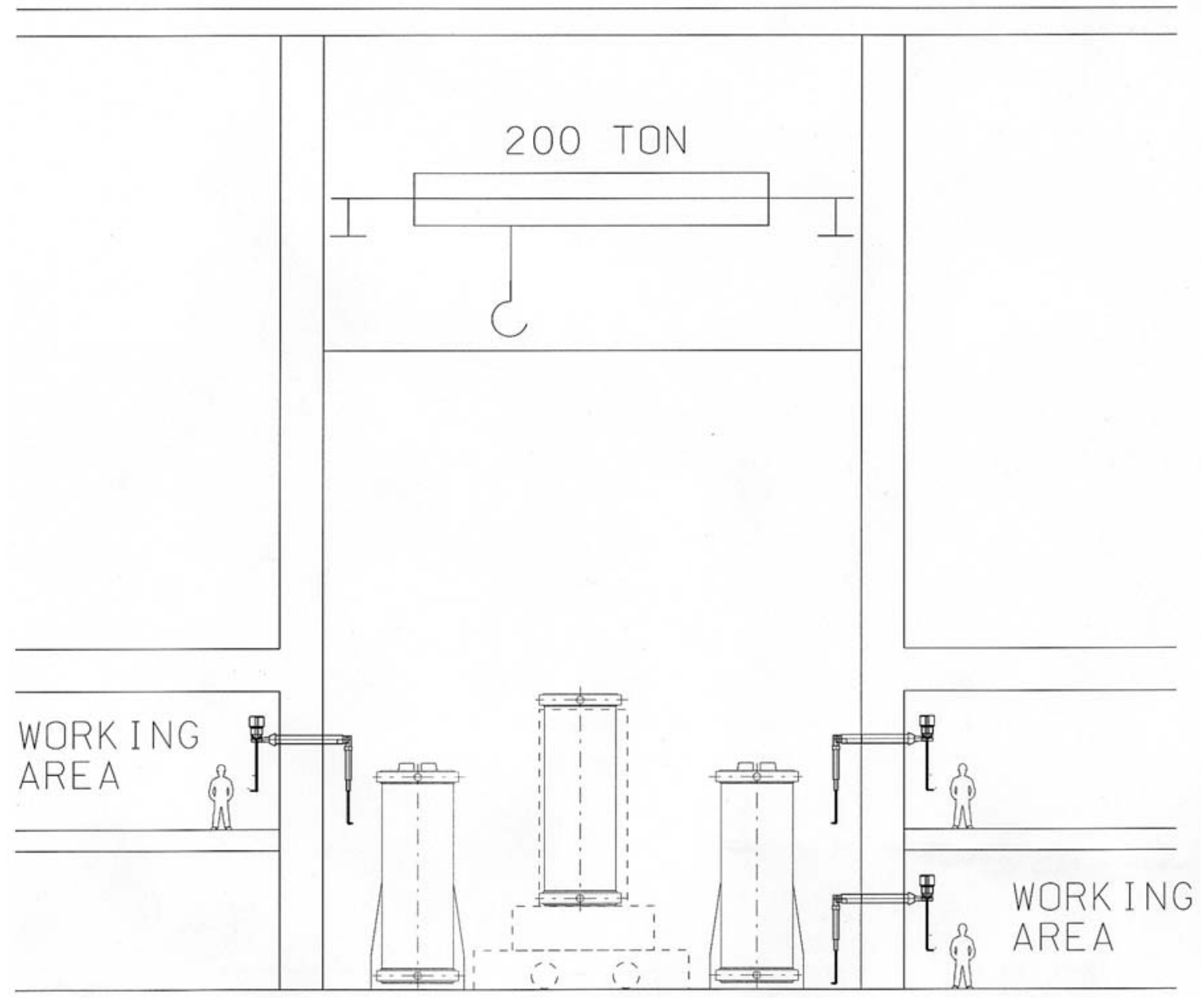

Figure 2. Dry Remediation Cell Section View 


\section{WP Operations}

Damaged and new WPs will enter the Dry Remediation Cell from the Waste Package Handling $\&$ Storage cell. The crane in the Waste Package Handling \& Storage cell will transfer the WP onto the Waste Package Decon transporter, which will be used to transfer the WP through the Waste Package Decon cell into the Dry Remediation Cell. The WP will be lifted off the transporter and loaded into one of the transfer station support stands . A new, undamaged WP or an empty cask will be located in the adjacent support stand port.

The top of the damaged WP will be removed to gain access to the internals of the WP. The top of the damaged WP may have to be cut off below the inner welded lid or the welds may have to be ground/cut out to allow access to the internal contents. It is assumed that if the WP is damaged and moved into the Dry Remediation Cell, it will not be reusable. Therefore, the contents of the damaged WP will be transferred to a new WP. In the event there are no new WPs configured to accept the contents of the damaged WP, or because of other operations direction, the contents of the damaged WP may be transferred to an empty cask.. For example, the cask could be a sitespecific cask to be sent to the staging/aging pad for future handling and disposition.

If the top of the waste package is removed, then the upper lifting trunnions will no longer be attached. In this case, the WP could not be lifted until the contents are removed, after which the WP would be loaded into an overpack for low-level waste (LLW) disposal. Before the WP can be sent for LLW disposal, the internals of the waste package will have to be evaluated to determine if any fissile material remains in the WP. If found, that material would have to be removed. As such, the Dry Remediation Cell will contain survey equipment and support equipment needed to retrieve fissile material left in a WP.

Once the new WP is loaded and the inner lid is installed, the WP would be lifted onto the transporter and moved back through the waste package decon cell, into the Waste Package Handling \& Storage cell, and transferred to one of the closure cells for final closure.

\section{Cask Operations}

Damaged casks will be moved from the Cask Dry Remediation DPC Preparation Room into the Dry Remediation Cell. The cask will be loaded into an open port in one of the support stands. Depending on the damage to the cask, the cask contents may or may not be removed from the cask. If the contents are removed, they may be transferred into a WP or into another cask. In general, the other cask will be a site-specific cask.

If the cask was sent to remediation because the lid could not be removed, special equipment, including impact wrenches, heaters, drills, and other necessary equipment, may be needed to remove the lid. There may also be damaged or stuck fuel in the cask. To resolve these conditions, additional equipment may be needed. As in the case of the WP, the cask will also have to be verified as being free of any residual fissile material. The NRC may want to be present during transfer or recovery from an off-normal cask incident.

If the damaged cask was emptied in the process facility but is not able to be sent off site, the problem may need to be fixed in the Dry Remediation Cell. In this case, no SNF/HLW will be 
transferred, but the cask will still be placed in one of the open support stands so that the appropriate work can be performed. Once the cask issues are resolved, the cask will be moved out of the Dry Remediation Cell, into the Cask Dry Remediation DPC Preparation Room, and then to the process line or to National Transportation for further use.

\section{DPC and Canister}

Canisters and DPCs will enter the Dry Remediation Cell in casks. All undamaged DPCs will be moved to the DPC cutting cell for processing of the contents through the waste transfer cell. Damaged DPC or DPCs with stuck or damaged fuel that cannot be handled in the waste transfer cell will be moved back into the Dry Remediation Cell and placed in the single DPC canister support stand for processing. As the DPC problem is resolved and the DPC is emptied, the contents will be moved from the DPC and placed in a WP or cask. The empty DPC will be loaded into an overpack for LLW disposal and moved out of the Dry Remediation Cell, into the Cask Dry Remediation DPC Preparation Room, and then out of the building through the cask lorry receipt/overpack entrance.

Canisters that are damaged (e.g., cannot be removed form a cask or will not fit into a WP) would be brought into the Dry Remediation Cell through the cask lorry receipt/overpack entrance and Cask Dry Remediation DPC Preparation Room, and moved into an open support stand port adjacent to the DPC canister support stand. Actions would then be taken to remove the canister from the cask and place it into another cask or specially modified WP. The canister may be moved into the DPC canister support stand for examination and a corrective action plan developed and approved. If necessary, the canister could be cut open and the internals repackaged for loading into a cask or WP. Alternatively, it may be determined that the canister can be repaired, which would also be done in the Dry Remediation Cell. If a canister has to be cut open and the contents removed, the empty canister will be loaded into an overpack for LLW disposal. Finally, it may be necessary to transfer the contents from a damaged canister into a new canister then seal the new canister. This sealing operation would generally require welding, but in some cases may be accomplished utilizing a bolted lid.

\section{Dry Remediation Cell Major Equipment}

The following list of major equipment is provided for information purposes only, and is not intended to be a complete list of equipment. It is also expected that as problems are identified and resolutions are developed, new and one-of-a-kind tools may be developed to support engineered solutions to the problems. Some of the equipment that will be needed for the Dry Remediation Cell are as follows:

- Overhead crane with a 200-ton capacity (loaded cask weight)

- Cranes and grapples that can transfer fuel elements, assemblies, and baskets

- Crane and grapples that can transfer canisters/DPCs

- Two stands that are capable of holding and restraining two sets of casks, WPs and/or Overpacks 
- Special stand for cutting open and working on WPs, DPCs, and canisters

- Cutting equipment to open WPs, DPCs, and canisters

- Friction lifting fixture or other design for lifting WPs without trunnions or for lifting DPCs and canisters

- Stands for cask lids and WP inner lid

- Five stations of master-slave manipulators on the second floor for access to the top of the containers, and one set of master-slave manipulators on the first floor, as shown in Figure 2

- Lead glass, oil-filled windows at each master-slave manipulator station

- Canister welding equipment

- A shielded crane docking area for crane maintenance

- A maintenance crane in the crane docking area.

\section{Conclusion}

Fuel handling and high-level waste handling at DOE sites is being conducted, as much as possible, in dry cells rather than in pools. The primary reason for dry cell usage is the cost of maintaining pools, which is resource intensive in staffing, equipment, and dollars. Dry cells also provide better control because of increased visibility and master-slave manipulator efficiency over reach rods. Additionally, techniques have been developed to maintain cleanliness in dry cells and minimize contamination spread even during bare fuel transfers.

For the purpose of maintaining efficiency and throughput in the dry transfer facility, it is recommended that the proposed Dry Remediation Cell be used for all remediation activities whenever possible. 